\title{
Rational Tax Enforcement
}

\author{
The Rt. Hon. The Lord Keith of Kinkel
}

Tax is not a popular subject except among those who hope to make money out of advising about it, or selling schemes aimed at avoiding or mitigating its incidence. However, the series of cases which started with Ramsay v. Inland Revenue Commissioners $^{1}$ has greatly reduced the number of concerns in the business of marketing tax avoidance schemes, and so many taxpayers have had their fingers burnt by the wares that they purchased so hopefully that there can be few nowadays who are tempted to take the risks involved. The reduction in the higher marginal rates of tax and the introduction of a $40 \%$ marginal rate of capital gains tax may also operate to the same effect.

The Ramsay series of cases, and particularly Furniss v. Damson, ${ }^{2}$ engendered serious doubts as to whether the principle enunciated in the Duke of Westminster's case $^{3}$ had been thrown completely overboard by the House of Lords. It was feared that in future any act by which a taxpayer so arranged his affairs that he was liable to pay less tax than he would otherwise have done might be struck down by the courts. It was felt in some quarters that the House of Lords had turned itself into an arm of the Inland Revenue dedicated to securing that all taxpayers so arranged their affairs as to be liable for the maximum amount of tax.

The features that distinguished Fumiss v. Damson from its predecessors were that the series of transactions there involved were not of a circular self-cancelling character, but had a commercial object in view, while the interposed step appeared to have certain definite and inescapable legal consequences. The intermediate company was on the face of it entitled, as a legal entity distinct from the original owner of the shares in question, to the proceeds of sale of these shares. It will be remembered that the scheme entered into involved the shareholders in an operating company transferring their shares to an Isle of Man subsidiary company in exchange for shares in the latter, which then sold the operating company shares on to a purchaser. Everything was carried through in one morning, in pursuance of an informal, non-contractual arrangement with the purchaser. The object was to

*The Denning Lecture 1989 under the auspices of the Bar Association for Commerce, Finance and Industry.

1. [1982] A.C. 300 .

2. [1984] A.C. 474. 
postpone liability to capital gains tax in reliance on paragraphs 4(2) and 6(1) of Schedule 7 to the Finance Act 1965. It was held that the disposal by the Isle of Man company fell to be disregarded for fiscal purposes. Capital gains tax was accordingly payable as though the shares in the operating company had been transferred directly to the purchasers and the purchase price had been received by the taxpayers.

Fumiss v. Damson was followed by a period of doubt as to its true ratio decidendi. The transfer of the shares to the intermediate company had been held by Commissioners to be a genuine and not a sham transaction, yet the fiscal consequences which by the provisions of paragraphs 4 and 6 of Schedule 7 to the Act of 1965 were to be attached to such a transaction were held not to apply. So it came to be thought by some that the case rested upon the principle that anything done with a view to avoiding or minimising tax upon a contemplated future transaction fell to be struck down. This view of the case was fostered to some extent by certain observations of Lord Diplock in I.R.C v. Burmah Oil Co. Ltd. ${ }^{4}$ and by Lord Scarman in Fumiss v. Damson itself. Lord Diplock said:

"It would be disengenuous to suggest, and dangerous on the part of those who advise on elaborate tax avoidance schemes to assume, that Ramsay's case did not mark a significant change in the approach of this House in its judicial role to a pre-ordained series of transactions (whether or not they include the achievement of a legitimate commercial end) into which there have been inserted steps which have no commercial purpose apart from the avoidance of a liability to tax which in the absence of those particular steps would have been payable. The difference is in approach."

Lord Scarman had appeared to introduce a moral dimension into the matter, by his reference to determining

"the limit beyond which the safe channel of acceptable tax avoidance shelves into the dangerous shallows of unacceptable tax evasion."

This supposed principle constituted the high water mark of the Inland Revenue's argument in the three cases reported under the name of Craven $\mathrm{v}$. White. ${ }^{6}$ Lord Oliver said:

"Your Lordships are thus invited ... to construct a general catch-all formula for rendering ineffective any step undertaken with a view to the avoidance or minimisation of tax on an anticipated transaction or disposition."7

The facts in all three cases presented a more or less close resemblance to those in Furmiss v. Dawson. In each of them assets, in one case land and in the other two

3. [1936] A.C. 1.

4. (1983) 54 T.C. 200 , at p.214.

5. Supra n.2, at p.513.

6. [1988] 3 W.L.R. 423.

7. At p.456. 
shares, had been transferred to subsidiary or sister companies in anticipation of a sale to an outside purchaser and with a view to avoiding or postponing a liability to tax which would have been incurred on a direct sale. In two of the cases the sale immediately in contemplation had not come to fruition, but a sale in one case to a different purchaser and in the other case to the same one had in fact been completed over a year later. In the third case, Craven v. White itself, two sets of negotiations were in progress at the time of the transfer to the intermediate company, and one of them was brought to a successful conclusion by a completed sale only a short time afterwards. The House of Lords decided unanimously that tax had been successfully avoided in the first two cases, and by a majority of three to two, also in the third case.

The most important effect of the case is that it laid to rest the idea that any transaction which is effected for the purpose of avoiding tax on a contemplated future transaction is, because it is "planned", necessarily to be treated as being one with the later transaction and having no independent effect. That proposition was not supported even by the minority in the House. The rationale of Ramsay v. Burmah Oil and Furniss v. Damson was put firmly on the basis of statutory construction. In regard to the circular, self-cancelling series of transactions which featured in the first two of these cases, the true effect of them was nil from the point of view of creating an allowance loss such as the legislation intended to make deductible in computing chargeable gains. Fumiss v. Damson was explained on the basis that the two interconnected transactions were equivalent in legal effect to a tripartite contract, this being the essence of the ratio decidendi contained in the speech of Lord Brightman. The two transactions were capable of being realistically treated as one indivisible whole involving only a single disposal for tax purposes. The intermediate company never acquired control of the operating company within the meaning of paragraphs 4 and 6 of Schedule 7 to the Act of 1965. Lord Oliver said:

\begin{abstract}
"As the law currently stands, the essentials emerging from Fumiss v. Dawson appear to me to be four in number: (1) that the series of transactions was, at the time when the intermediate transaction was entered into, pre-ordained in order to produce a given result; (2) that the transaction had no other purpose than tax mitigation; (3) that there was at that time no practical likelihood that the pre-planned events would not take place in the order ordained, so that the intermediate transaction was not even contemplated as having an independent life; and (4) that the pre-ordained events did in fact take place. In these circumstances the court can be justified in linking the beginning with the end so as to make the single composite whole to which the fiscal results of the single composite whole are to be applied."
\end{abstract}




\section{Later he said:}

"[I do not] consider that the Ramsay approach, while no doubt applicable to a much wider variety of transactions than those described in the instant appeals, requires further exposition or clarification. Its basis is manifest and has been clearly explained by Lord Wilberforce. What the apellants urge upon your Lordships is a restatment of the approach in a formula based, as it seems to me, not upon seeking to identify the reality of sequential transactions, but upon a much wider, but at the moment unidentified general principle of judicial disapprobation of the lawful rearrangement of the subject's affairs designed to produce a result which is fiscally advantageous to him in relation to a transaction into which he anticipates entering. That is essentially a legislative exercise and one upon which, in my opinion, your Lordships should hesitate long before entering."

Lord Templeman, who dissented on the result in Craven v. White but not in the other two appeals, took the view that if the taxpayer planned to carry out a transaction which would normally attract tax by combining it with another transaction solely designed to avoid tax, and the whole scheme was eventually carried through, then the intermediate transaction in every case fell to be disregarded for fiscal purposes. It made no difference that the final transaction was not certain to be completed at the time the intermediate transaction took place, nor that a considerable interval of time might intervene between them. Craven v. White was caught because the final stage of the pre-planned scheme actually took place. In the other two cases the final stage originally planned did not take place. The eventual disposal was not part of the original plan, so these cases were not caught.

In the result, taxpayers and their advisers must now have a reasonably clear understanding of the limits of the Ramsay principle and what steps towards tax avoidance or mitigation they may safely take without incurring liability. It is plainly highly desirable that the law should be clear in this respect. It remains the law that artificial transactions which from beginning to end have no other purpose than tax avoidance have no utility for achieving that purpose. It has also been made clear that arrangements made with a view to avoiding tax on some genuine transaction which may be contemplated as likely to be carried through in the future are not vulnerable to being struck down judicially. It is for Parliament, not the courts, to set the parameters beyond which tax avoidance may not legitimately and effectively be carried on.

The Committee on tax enforcement powers of which I was chairman and which reported in 1983 looked fairly briefly at tax avoidance. It made two recommendations in this field which were directed at securing that the revenue departments might more readily gain access to information about what transactions had actually taken place in the course of a tax avoidance scheme. If a 
taxpayer has been advised that such a scheme has resulted in no liability to tax, he may think there is no need to disclose its existence in his return. One witness before the Committee said:

"The taxpayer builds a tax-proof castle: if the Inspector could see inside he would see the weakness in the castle's structure, but the taxpayer does all he can to make sure that the Inspector never sees inside it."

To meet this sort of case the Committee recommended that there should be included in the tax return a question on the lines:

"In making this return have you taken the benefit of any doubt about whether any item ought to be declared, or any relief or deduction allowed? If so give brief details."

This recommendation was rejected by the Government.

The other relevant recommendation was in the field of legal professional privilege. A taxpayer is not entitled to keep his affairs confidential in a question with the revenue departments, and it seemed to the Committee that there was room for the view that legal professional privilege should not be capable of being manipulated so as to secure such a result. The Committee had evidence that the details of tax avoidance schemes were on occasion recorded only in instructions to counsel to advise, with a view to these details being kept secret from the revenue. The privilege belongs to the taxpayer, not to the professional adviser, and logically there seemed much to be said for his being obliged to waive it in particular circumstances. So the Committee recommended that, subject to stringent safeguards, the privilege should be capable of being overridden by the court where the ascertainment of facts necessary to the proper determination of a tax liability would otherwise be unreasonably impeded. This recommendation was naturally strongly opposed by the Law Society and other professional bodies, and the Government has decided to reject it.

These were, however, fairly peripheral aspects of the Committee's report. The most important aspects were those at the centre of the tax enforcement system, particularly for income and corporation tax and VAT. In the introduction to the report the Committee said:

"At an early stage we formed the view that the mechanisms which the Board

of Inland Revenue were striving to operate were in many respects antidiluvian and quite unsuited to modern conditions."

One of the most unsatisfactory features of the existing system was that every year about 1.8 million estimated assessments on trading profits were made in the absence of timely returns, and that in no less than 1.7 million cases use of the appeal machinery was needed to compel the production of tax returns and accounts. As regards penalties for late or defective returns, these could only be exacted on being imposed by the appeal Commissioners and could amount to as 
much as 200 per cent of the tax due for fraud and 100 per cent for neglect. ${ }^{10}$ The Committee proposed the introduction of three categories of default carrying automatic penalties which would be assessed as tax by the inspector, always subject to appeal to the Commissioners. The first category, "Default Class A", was to be civil fraud, being the deliberate omission or understatement of amounts in tax returns with the dishonest intention of deceiving the revenue and evading tax. Here the penalty was to be the tax due plus default interest plus a maximum of 100 per cent of the tax underpaid, mitigable to 50 per cent for co-operation in the investigation. The second category, described as "Default Class B" or "gross negligence", consisted in the omission or understatement in tax returns of an amount arithmetically calculated or lesser but repeated omissions or understatements. Here the penalty was to be the tax due plus default interest plus 30 per cent of the tax underpaid, non-mitigable. The third category, "Default Class C", was to be any error leading to the omission or understatement in a tax return of any amount not within Default Classes A or B. The penalty was to be the tax due plus default interest only.

In February 1986, the Board of the Inland Revenue put out a consultative document including draft clauses, certain of which would have introduced automatic penalties on the lines proposed by the Committee, but subject to modification. In July 1988, a further consultative document was issued which proposed to drop these clauses and, instead, simply to amend section 95 of the Taxes Management Act 1970 by removing the obsolete fixed penalty of $£ 50$ and reducing the 200 per cent limit to 100 per cent, which would be fully mitigable. This contrasts with the new regime for VAT penalties, already introduced by the Finance Act 1985, which I shall be considering later. It remains accepted, however, that the income tax penalties should be assessed by the Inspector as additional tax, subject to appeal to the Commissioners.

One of the most vexatious problems addressed by the Committee related to late returns of income both by trading and by non-trading taxpayers, and the non-delivery of accounts. It is this that lies at the heart of the excessive use of the appeal machinery to compel compliance. At present an income tax return is required to be completed and sent back within 30 days of its issue, and failure to do so is technically, but never in practice, subject to penalty. This is obviously a completely unrealistic requirement in the great majority of cases, and the Committee recommended that the time limit be increased to three months, with provision for extension up to six months with the approval of the Inspector, and subject to automatic penalties for late returns. It was also proposed that trading taxpayers should be required to submit accounts in support of their tax returns not later than twelve months after the end of their accounting years, with provision for gradually reducing this to seven or six months. Where the accounts were not available when the return was sent in, it was proposed that the profits for the 
preceding accounting year should be entered. In the latest consultation paper issued by the Inland Revenue (July 1988), these proposals have all been rejected, at least at this stage, for non-trading taxpayers and unincorporated traders.

However, in relation to corporation tax Parliament has already enacted, in sections 82 to 91 of the Finance (No.2) Act 1987, a new system known as Pay and File. This is not to come into effect until 1992 at the earliest, in order to enable companies and their accountants to make the necessary preparations, and also because the Revenue will need to equip itself with new computer facilities in order to administer the new system. Broadly speaking, the effect of the Pay and File regime will be that a company will be required to make its own assessment of the corporation tax due and pay it on the usual due date nine months after the end of its accounting period. However, no proceedings for collecting the tax can be instituted, if the company does not pay at that stage, until the Inspector has made an assessment on the company and thirty days have elapsed from the notice of it. The company is to have twelve months from the end of its accounting period to send in its return and accounts. If it fails to do so it will incur an automatic penalty unless it can show a reasonable excuse for the failure. The penalty will start at $£ 100$ and increase in steps up to $£_{1} 1,000$ according to the length of the delay and the number of occasions on which the company has previously been in default, together with 10 per cent of the unpaid tax if the return is up to two years late and 20 per cent if the delay is over two years. When the final tax liability is settled interest will be payable to the Revenue, as from the due date for payment of tax, on any amount by which the payment then made is less than that eventually assessed, and will be payable by the Revenue to the taxpayer on the amount of any excess payment, which will itself, of course, be repaid by the Revenue, subject to any set-off.

The Pay and File regime will include the introduction of a new form of corporation tax return, the details of which are being worked out between the Revenue and representatives of companies and the accounting profession. A considerable amount of attention is given in the July 1988 consultative document to the appropriate rates of interest on underpayments and overpayments of tax. It is proposed that all interest should be simple and not compounded and that it should be paid without deduction of tax and left out of account for all tax purposes. The rate of interest on overdue tax is proposed to be 2.5 per cent over base rate, and that on repayments base rate minus 1 per cent.

These changes or proposed changes seem to offer some prospect of bringing about improved compliance without imposing excessive burdens on taxpayers, and of reducing the previous excessive reliance on the appeal machinery, though they do not go so far as the Committee would have liked. It would be tedious and time-wasting to try and go through many other aspects of the Committee's recommendations which have been either accepted or rejected by the Government. However, it is of some interest that there has been acceptance of the proposal that the Revenue's powers under section 20 of the Taxes Management 
Act 1970 should be enlarged by enabling it to require a taxpayer to answer written questions, in addition to producing documents called for. There has also been acceptance that the third parties who can be required to produce documents should no longer be limited to certain close relatives of the taxpayer together with, as regards business profits, any person carrying on a business and any company whether carrying on business or not. The present intention seems to be to make all third parties subject to the requirement to produce documents, but the prior approval of an appeal Commissioner will be required, as indeed it will be for all requests for documents or particulars.

The present state of play as regards the Committee's recommendations on income and corporation tax appears to be that 28 have been accepted in detail or in principle, 20 have been accepted with modification, 22 have been rejected and 9 have been reserved for further consideration. Full implementation of the accepted recommendations cannot, however, be expected until well into the $1990 \mathrm{~s}$, since it depends to a large extent on computerisation of Inland Revenue operations.

In the field of VAT matters have moved much further and faster. The Committee made 59 recommendations relating to VAT. Of these 38 were accepted and have been enacted, 10 have been accepted with modifications and enacted, 9 were rejected and two are still being considered. Of those rejected, five related to legal professional privilege. Others rejected were concerned with the publication of the names of offenders, the level of judicial authority for issuing warrants for VAT searches (it was proposed to raise the level in England and Wales from magistrate to Circuit Judge), notification of taxpayers before disclosures to foreign revenue authorities, and jeopardy assessments.

The principal aspect of VAT enforcement with which the Committee found fault was that almost all failures by the taxpayer, including breaches of regulatory provisions, were subject to criminal prosecution. This regime had been carried over from Purchase Tax. Its existence caused much indignation among bodies such as the National Federation for the Self-Employed. In practice, the number of defaulters prosecuted was very small. It was estimated that in the autumn of 1982, out of about one million traders expected to make VAT payments, more than 375,000 were at least one month late and more than 130,000 two months late. Customs and Excise had insufficient resources to enable more than 16,000 traders to be included in any prosecution routine at any one time. In 1980-81, there were 3,767 prosecutions for failure to furnish returns and 739 for failure to pay tax. There was no provision for payment of interest on overdue tax.

It seemed to the Committee that this was highly unsatisfactory. Not only did prosecution appear quite unsuited to securing compliance with purely regulatory requirements, but it was rarely invoked and massive amounts of tax were regularly outstanding with substantial loss to public revenue. So the Committee proposed the abolition of the criminal sanction for regulatory matters and the substitution of civil penalties, together with the introduction of default interest on underpayments of tax or overclaims. It also recommended the introduction of two new types of 
"civil default". The first was described as "gross negligence" (the description "serious misdeclaration" has now been adopted), covering defaults of a large or persistent character. The test was to be objective, turning on the size of an understatement or overclaim and whether it was repetitive. The default was to attract a fixed rate, non-mitigable penalty of 30 per cent of the tax understated or overclaimed, together with default interest. The second type of default was described as "civil fraud", defined as an act or omission designed to deceive Customs and Excise with the object of evading VAT. The penalty was to be 100 per cent of the tax evaded, mitigable down to 50 per cent according to the degree of co-operation received from the taxpayer during the investigation, together with default interest. The Committee recommended that all civil penalties and default interest should be assessed as tax, with a right of appeal to the VAT Tribunal. It will be seen that this regime closely resembled that proposed for income and corporation civil penalties. A further important recommendation was that failure to notify liability to registration for VAT or the unauthorised issue of VAT invoices should constitute the civil offence of "gross negligence" attracting the non-mitigable penalty of 30 per cent of the tax involved, together with default interest. It was also proposed that for failure to furnish returns or not paying the tax in time there should be a new tariff of civil penalties at daily rates with tax-geared alternatives, starting at the third default in any period of two years, and a tariff of daily rates for failure to keep records or supply information when required to do so.

All these recommendations were implemented by sections 13 to 21 of the Finance Act 1985. The penalties, except that for civil fraud, were made subject to the defence of reasonable excuse. This was not in the Bill as first published, but was added by amendment largely due to representations by members of the Committee. Consideration of this defence now forms a large part of the work of the VAT Tribunals. All the provisions did not come into effect at once. The penalty for failure to notify liability to registration came into force from the date of the Royal Assent. Customs and Excise regarded this as one of the most important provisions operationally, since a taxpayer cannot be controlled until he is registered. However, sustained criticism of the measure was encountered, largely because the fixed penalty of 30 per cent of the tax was considered harsh, and defaulters were found to be largely ignorant rather than negligent. So amendments were introduced in the Finance Act 1988, whereby the penalty was reduced to 20 per cent where the delay does not exceed 18 months and 10 per cent where it does not exceed nine months. Customs and Excise regard the results of the provison as beneficial. The level of imposition of penalties runs at just over 3 per cent of new registrations, and the value of penalties to the end of December 1988 amounts to $£ 16,679,016$.

The civil fraud penalty regime did not become operational till the summer of 1987. The policy has been to apply the criminal standard of proof, that of beyond reasonable doubt, rather than the civil standard of balance of probabilities. By the 
end of 1988,538 penalties had been assessed. There had been 33 appeals of which 9 were withdrawn and 24 were still awaiting hearing. The value of penalties assessed to 31 December 1988 amounts to $£ 2,334,789$. The provisions about default interest and serious misdeclaration penalties were due to be put into effect in July 1988, but it was decided to defer this until late 1989. So there is as yet no indication of how this part of the package will work.

The default surcharge provisions were implemented on 1 October 1986, but surcharges did not start to be assessed until May 1987. The regime appears to have had considerable success. The percentage of registered traders who are liable for tax and fail to furnish returns by the due date has fallen from 40 per cent to 17 per cent. This result is thought to be largely due to the widespread advance publicity given to the measures. By the end of 1988, 1343 appeals against surcharge assessments had been lodged with VAT Tribunals. Of these 391 had by then been withdrawn, 203 dismissed and 80 upheld. The average value of tax arrears outstanding at any time has fallen fairly dramatically over the period, and Customs and Excise consider that they are well on the way towards halving, by early 1989, the average arrears outstanding at mid-1985. The reduction so far is estimated to be nearly $£ 700$ million, directly related to the implementation of the Committee's recommendations.

In October 1986, the Government instituted a review of the effects on small businesses of the 1985 legislation and a number of other matters. One result was the introduction of a cash accounting system for businesses having an annual turnover not exceeding $£ 250,000$. This means that such businesses account for VAT on the basis of payments received rather than that of invoices issued, and is of considerable benefit to them from the point of view of cash flow and automatic relief for bad debts. Another result of the review was that it was found that the requirement to keep records for six years rather than three years, a change recommended by the Committee, did not impose an undue burden on small businesses. In addition the impact of the penalty provisions was modified in certain respects, in particular by amending the law so that late registration should not attract default interest as well as default surcharges.

In all the circumstances the members of the Committee can reasonably feel that their labours have not been in vain. It is not uncommon for a departmental Committee or even a Royal Commission to find its report pigeon-holed indefinitely. In this instance, however, Governmental action has been as speedy as could reasonably have been expected in the two fields which I have been discussing. The result in both of them, it may well be thought, is to put in place a much more rational and more effective system than previously existed. The new VAT regime is 'vell on the way to being fully operational, although for reasons with which one can have some sympathy matters are not yet nearly so advanced on the income and corporation tax front. Although I have not so far specifically mentioned it, it should not be forgotten that practically all the measures recommended by the Committee for better procedures, less burdensome and 
oppressive to the citizen, in connection with searches for evidence of fraud, production of documents and other matters which in the past have caused considerable friction have been implemented either by legislation or by administrative action. All this, of course, is not just a cause for self-congratulation on the part of the Committee. It is to be hoped that it may be seen as a benefit to the great and conscientious majority of taxpayers, and also, though in different ways, to the minority which is noţ so conscientious. 